\title{
EFEK IMUNOMODULATOR EKSTRAK ETANOL KULIT BUAH NANAS (Ananas comosus L.Merr) TERHADAP MENCIT PUTIH JANTAN DENGAN METODE BERSIHAN KARBON (Carbon Clearance)
}

\author{
Masayu Azizah, Wiwik Wiraningsih, Ema Ratna Sari \\ Sekolah Tinggi Ilmu Farmasi Bhakti Pertiwi Palembang \\ E-mail korespondensi : zizaloeng@gmail.com
}

\begin{abstract}
Abstrak
Upaya untuk meningkatkan sistem pertahanan tubuh menjadi sangat penting dilakukan melalui pemberian imunomodulator. Penelitian ini dilakukan untuk mengetahui efek imunomodulator dari ekstrak etanol kulit buah nanas (Ananas comosus L. Merr) terhadap mencit putih jantan dengan metode bersihan karbon. Hewan dibagi atas 5 kelompok, yang terdiri dari: Kelompok 1 diberi tween 80 1\% v/v; Kelompok 2 diberi ekstrak meniran; Kelompok 3, 4 dan 5 diberi ekstrak etanol kulit buah nanas dengan dosis berturut-turut $125 \mathrm{mg} / \mathrm{kg} \mathrm{BB}, 250 \mathrm{mg} / \mathrm{kg} \mathrm{BB}$, dan $500 \mathrm{mg} / \mathrm{kg} \mathrm{BB}$, selama 6 hari secara oral. Pada hari ke-7 hewan diinjeksi dengan suspensi karbon melalui vena ekor $0,2 \mathrm{ml} / 20 \mathrm{~g} \mathrm{BB}$, darah diambil pada menit ke-5 dan 15 melalui retro vena orbital menggunakan pipa kapiler, kemudian sampel dilisis dengan $4 \mathrm{ml}$ natrium karbonat $0,1 \% \mathrm{~b} / \mathrm{v}$ dan diukur absorbannya pada panjang gelombang 675 $\mathrm{nm}$ menggunakan spektrofotometer visible. Hasil penelitian menunjukkan ekstrak etanol kulit buah nanas memiliki efek imunomodulator dimana dosis yang paling baik adalah $250 \mathrm{mg} / \mathrm{kgBB}$.
\end{abstract}

Kata kunci: biological response modifiers, imunomodulator, kulit buah nanas (Ananas comosus L.Merr)

\begin{abstract}
This research was aimed to study the immunomodulatory effect of ethanol extract of pineapple (Ananas comosus L. Merr) peel on white male mice with carbon clearance method. Animals were divided into 5 groups: Group 1 was given tween $801 \%$ v/v;Ggroup 2 was given meniran extracts; Group 3, 4 and 5 were given ethanol extracts of pineapple peel with a dose of $125 \mathrm{mg} / \mathrm{kg} \mathrm{BW,} 250$ $\mathrm{mg} / \mathrm{kg} \mathrm{BW}$, and $500 \mathrm{mg} / \mathrm{kg} \mathrm{BW}$, respectively, for 6 days orally. On the $7^{\text {th }}$ day the animals were injected with carbon suspension 0.2 $\mathrm{ml} / 20 \mathrm{~g} \mathrm{BW}$ at the tail vein. Blood was taken at $5^{\text {th }}$ and $15^{\text {th }}$ minutes using capillary pipe from the animal's orbital retro vein, then it was diluted with $4 \mathrm{ml}$ of $0.1 \% \mathrm{~b} / \mathrm{v}$ sodium carbonate and measured its absorbance at $675 \mathrm{~nm}$ using visible spectrophotometer. The ethanol extract of pineapple peel showed immunomodulatory effect where the best dose was $250 \mathrm{mg} / \mathrm{kg} \mathrm{BW}$.
\end{abstract}

Keywords : biological response modifiers, immunomodulatory, pineapple peel

\section{PENDAHULUAN}

Pola hidup modern menuntut segala sesuatu dilakukan secara cepat dan instan. Kualitas makanan yang dikonsumsi, polusi udara, kurang berolahraga dan stres dapat menyebabkan daya tahan tubuh akan terus menurun. Kondisi tersebut menyebabkan mikroba patogen seperti virus, bakteri, parasit, jamur mudah masuk dan menyerang tubuh sehingga timbul berbagai penyakit infeksi dan penyakit degeneratif, bahkan dapat menyebabkan penuaan dini (Imron dkk, 2016).

Upaya untuk meningkatkan sistem pertahanan tubuh menjadi sangat penting dilakukan melalui pemberian imunomodulator. Imunomodulator atau biological response modifiers, yaitu zat-zat yang mempengaruhi reaksi biologis tubuh terhadap zat-zat asing. Imunomodulator terdiri dari imunostimulator yang berfungsi untuk meningkatkan fungsi dan aktivitas sistem imun dan imunosupresor yang dapat menghambat atau menekan aktivitas sistem imun (Tjay dan Rahardja, 2007).

Bahan yang dapat menstimulasi sistem imun terdiri dari dua kelompok yaitu bahan sintetik dan biologis. Bahan sintetik antara lain adalah senyawa muramil dipeptida (MDP) dan levamisol, sedangkan biologis diantaranya adalah sitokin (interleukin-2) (Tizard, 2000). Penggunaan bahan sintetik maupun biologis mempunyai kekurangan, seperti pada sitokin (interleukin-2) yang mempunyai efek samping pada sistem saraf pusat yang dapat menimbulkan delirium dan levamisol yang mempunyai efek samping agranulositosis (Departemen farmakologi dan terapeutik FKUI, 2012). Dengan demikian lebih aman jika memanfaatkan bahan alam yang mempunyai efek imunomodulator.

Salah satu tanaman yang banyak diminati oleh masyarakat adalah buah nanas. Buah nanas tersebut menyisakan limbah kulit yang belum dimanfaatkan secara optimal. Kulit buah nanas diidentifikasi kaya akan fenolik dan flavonoid (Hatam dkk, 2013) serta tanin, saponin dan steroid/triterpenoid (Parveena dan Estherlydia, 2014). Flavonoid merupakan salah satu senyawa yang diduga berpotensi sebagai imunomodulator (Nugroho, 2012). Adanya efek imunomodulator diduga juga karena aktivitas antioksidan yang tinggi dari ekstrak etanol kulit buah nanas (Emmanuel dkk, 2016).

\section{METODE}

\section{a. Sampel Penelitian}

Sampel berupa kulit buah nanas segar, diambil dari buah nanas ditandai dengan daging yang masih mengkal dan kulit berwarna kuning kehijauan. Sampel kulit buah nanas sebelum dimaserasi dirajang terlebih dahulu dengan tujuan agar pelarut dapat berpenetrasi dengan mudah sehingga penarikan zat aktif lebih sempurna. Proses ekstraksi dengan cara maserasi menggunakan etanol destilat sebagai pelarut, karena etanol merupakan pelarut yang bersifat universal yang bisa melarutkan senyawa polar, semipolar maupun nonpolar dan etanol tidak toksik terhadap hewan uji (Marjoni, 2016). 
Tabel 1. Rerata parameter konstanta fagositosis

\begin{tabular}{cc}
\hline Kelp Perlakuan & Konstanta Fagositosis \\
(Rerata \pm SD)
\end{tabular}

$\begin{array}{lc}\text { Kontrol negatif } & 0,0348 \pm 0,0029 \\ \text { Kontrol Positif } & 0,0956 \pm 0,0065 \\ \text { Dosis } 125 \mathrm{mg} / \mathrm{kgBB} & 0,0427 \pm 0,0034 \\ \text { Dosis } 250 \mathrm{mg} / \mathrm{kgBB} & 0,0733 \pm 0,0064 \\ \text { Dosis } 500 \mathrm{mg} / \mathrm{kgBB} & 0,0473 \pm 0,0049\end{array}$

Hasil maserasi disaring kemudian diuapkan dengan destilasi vakum untuk mengurangi jumlah pelarut dan dirotary evaporator sampai didapatkan ekstrak kental yang tidak dapat dituang ekstrak yang didapatkan di uji fitokimia untuk melihat kandungan senyawa yang terkandung dalam ekstrak etanol kulit buah nanas.

\section{b. Cara Kerja}

Uji efek imunomodulator dilakukan dengan metode bersihan karbon. Pada uji ini mencit putih jantan yang berumur 2-3 bulan dan bobot 20-30 gram, dikelompokkan menjadi 5 kelompok, setiap kelompok terdiri dari 5 ekor mencit yang diberi perlakuan berbedabeda yaitu:

Kelompok I: Kontrol negatif diberikan suspensi tween 80 $1 \% \mathrm{v} / \mathrm{v}$.

Kelompok II: Kontrol positif diberikan suspensi ekstrak kering meniran dengan dosis $6,5 \mathrm{mg} / \mathrm{kgBB}$.

Kelompok III: Diberikan ekstrak etanol kulit buah nanas dosis $125 \mathrm{mg} / \mathrm{kgBB}$.

Kelompok IV: Diberikan ekstrak etanol kulit buah nanas dosis $250 \mathrm{mg} / \mathrm{kgBB}$.

Kelompok V: Diberikan ekstrak etanol kulit buah nanas dosis $500 \mathrm{mg} / \mathrm{kgBB}$.

Tiap-tiap hewan percobaan diberikan sediaan uji secara peroral satu kali sehari selama 6 hari berturutturut, pada hari ke 7 mecit diinjeksi kembali dengan suspensi karbon melalui vena ekor 0,2 ml/20gBB, kemudian darah diambil melalui retro vena orbital pada menit ke 5 dan 15 menggunakan pipa kapiler sebanyak $80 \mu \mathrm{l}$, lalu darah dilisis dengan $4 \mathrm{ml}$ natrium karbonat $0,1 \% \mathrm{~b} / \mathrm{v}$ dan diukur serapannya pada panjang gelombang $675 \mathrm{~nm}$ menggunakan spektrofotometer UVVis (Nassar dkk, 2015).

Di hitung konstanta fagositosis (K) (Shah dkk, 2008) dan waktu paruh karbon dalam darah ( $\left.\mathrm{t}_{1 / 2}\right)$ (Nassar dkk, 2015) dengan menggunakan rumus:
$\mathrm{K}=\frac{\ln _{O D 1}-\ln _{O D 2}}{t_{2}-t_{1}}$ $\mathrm{t} 1 \frac{1}{2}=\frac{0,693}{K}$
Keterangan:
$\mathrm{K}$ : Konstanta fagositosis
In oDI : Absorban awal
In OD2 : Absorban akhir
$\mathrm{t}_{1} \quad$ : Waktu awal
$\mathrm{t}_{2}$ : Waktu akhir
$\mathrm{t}_{1 / 2} \quad$ : Waktu paruh eliminasi karbon

\section{HASIL DAN PEMBAHASAN}

Hasil uji fitokimia menunjukkan bahwa ekstrak etanol kulit buah nanas mengandung flavonoid, fenolik, saponin dan steroid. Rerata konstanta fagositosis kelompok kontrol negatif, kontrol positif dan ekstrak etanol kulit buah nanas dengan dosis $125 \mathrm{mg} / \mathrm{kgBB} ; 250 \mathrm{mg} / \mathrm{kgBB}$; $500 \mathrm{mg} / \mathrm{kgBB}$.

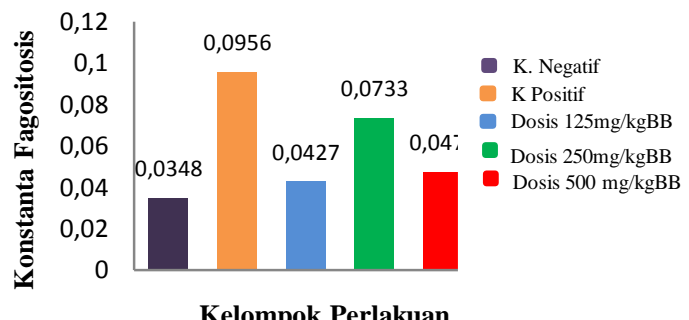

Gambar 1. Diagram batang parameter konstanta fagositosis

b. Rerata waktu paruh kelompok kontrol negatif, kontrol positif dan ekstrak etanol kulit buah nanas dengan dosis $125 \mathrm{mg} / \mathrm{kgBB} ; 250 \mathrm{mg} / \mathrm{kgBB} ; 500 \mathrm{mg} / \mathrm{kgBB}$.

Tabel 2. Rerata parameter waktu paruh

$$
\begin{gathered}
\text { Kelompok Perlakuan } \quad \text { Waktu Paruh (menit) } \\
\text { (Rerata } \pm \text { SD) }
\end{gathered}
$$

Kontrol Negatif
Kontrol Positif

Dosis $125 \mathrm{mg} / \mathrm{kgBB}$

Dosis $250 \mathrm{mg} / \mathrm{kgBB}$

Dosis $500 \mathrm{mg} / \mathrm{kgBB}$
$20,0526 \pm 1,7385$

$7,2758 \pm 0,4674$

$16,3296 \pm 1,3394$

$9,5114 \pm 0,8102$

$14,7812 \pm 1,5552$

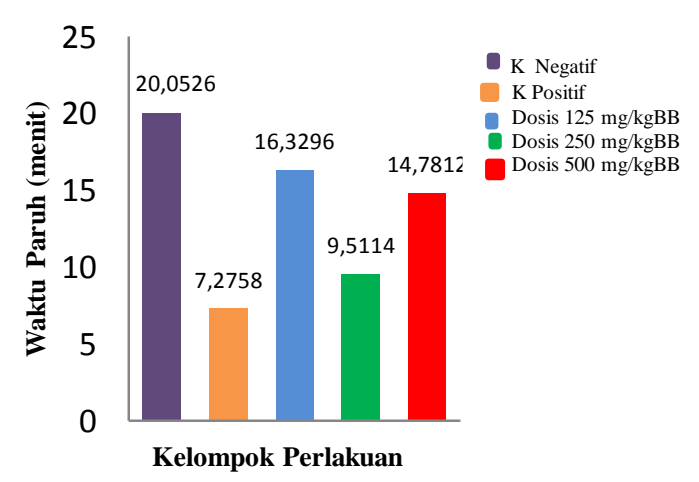

Gambar 2. Diagram batang parameter waktu paruh

Parameter yang digunakan dalam pengujian efek imunomodulator adalah konstanta fagositosis dan waktu paruh. Konstanta fagositosis yang digunakan untuk menentukan kecepatan fagositosis. Semakin besar nilai konstanta fagositosis maka akan semakin tinggi kecepatan bersihan karbon yang berarti semakin cepat sel fagosit melakukan proses fagositosis. Sedangkan waktu paruh digunakan untuk melihat pengaruh bahan uji terhadap proses fagositosis, ditandai dengan jumlah 
karbon yang berkurang dalam darah seiring bertambahnya waktu. Jadi semakin sedikit waktu yang diperlukan untuk menjadi separuhnya maka akan semakin cepat pula karbon tereliminasi.

Berdasarkan hasil penelitian, didapatkan nilai absorban dari pengukuran menggunakan spektrofotometer UV-Vis pada panjang gelombang $6 \mathrm{kk} 75$ $\mathrm{nm}$. Dari data absorban tersebut digunakan untuk menghitung nilai konstanta fagositosis dan waktu paruh karbon dalam darah. Pada kelompok dosis yang diberikan ekstrak etanol kulit buah nanas memiliki nilai konstanta lebih besar dan waktu paruh lebih kecil dibandingkan kontrol negatif, yang hanya diberikan tween 80 1\% v/v yang tidak memiliki efek imunomodulator. Namun lebih rendah dibandingkan dengan kontrol positif. Dari hasil nilai konstanta fagositosis dan nilai waktu paruh menunjukkan bahwa setelah pemberian ekstrak etanol kulit buah nanas selama enam hari dapat meningkatkan kemampuan sel fagosit dalam memfagositosis karbon sehingga jumlah karbon berkurang dalam darah.

Pada hasil uji statistik one way anova menunjukkan bahwa nilai konstanta fagositosis dan waktu paruh memiliki perbedaan yang bermakna pada setiap kelompok perlakuan $(p<0,05)$ dan Pada hasil uji Duncan menunjukkan bahwa nilai konstanta fagositosis dan waktu paruh pada semua kelompok perlakuan terletak pada subset yang berbeda, kecuali pada kelompok dosis $125 \mathrm{mg} / \mathrm{kgBB}$ dengan dosis $500 \mathrm{mg} / \mathrm{kgBB}$ yang terletak dalam satu subset. Hal ini menunjukkan bahwa kelompok dosis $500 \mathrm{mg} / \mathrm{kgBB}$ mengalami penurunan efek sehingga memiliki efek imunomodulator yang sebanding dengan kelompok dosis $125 \mathrm{mg} / \mathrm{kgBB}$. Sedangkan efek imunomodulator yang paling baik ditunjukkan oleh kelompok pembanding (kontrol positif) diikuti oleh kelompok dosis $250 \mathrm{mg} / \mathrm{kgBB}$, dosis $500 \mathrm{mg} / \mathrm{kgBB}$, dosis $125 \mathrm{mg} / \mathrm{kgBB}$.

Pada kelompok dosis $125 \mathrm{mg} / \mathrm{kgBB}$ dan $250 \mathrm{mg} / \mathrm{kgBB}$ yang menunjukkan adanya efek imunomodulator dengan aktivitas sebagai imunostimulator dengan peningkatan nilai konstanta fagosistosis dan kecilnya waktu paruh dikarenakan kemungkinan dikarenkan adanya senyawa flavonoid. Senkkyawa flavonoid diduga yang berperan dalam meningkatkan atau merangsang sel-sel fagosit untuk merangsang respon fagositosis (Nugroho, 2012) dan senyawa-senyawa antioksidan lainnya yang diduga dapat meningkatkan aktivitas dan kapasitas makrofag untuk melakukan fagositosis (Chao dkk, 2004).

Pada kelompok dosis $250 \mathrm{mg} / \mathrm{kgBB}$ kemungkinan merupakan dosis optimum dalam efek imunomodulator yang mempunyai aktivitas sebkkagai imunostimulator, sehingga pada kelompok $500 \mathrm{mg} / \mathrm{kgBB}$ mengalami penurunan efek imunomodulator dengan aktivitas imunostimulator, hal ini kemungkinan dikarenakan dengan peningkatan dosis yang berarti meningkatnya jumlah senyawa yang terkandung didalam kulit buah nanas, seperti halnya pada saponin yang pada jumlah normal dapat berperan sebagai imunostimulator sedangkan dalam jumlah yang melebihi normal dapat berperan sebagai imunosupresor (Francis, dkk). Sehingga pada dosis $500 \mathrm{mg} / \mathrm{kgBB}$ telah menimbulkan efek imunosupresor, dimana terjadinya penghambatan respon imun, yang ditandai dengan kecepatan bersihan karbon yang melambat dan waktu paruh menjadi lebih lama.

\section{SIMPULAN}

Ekstrak etanol kulit buah nanas (Ananas comosus L. Merr) memiliki efek imunomodulator terhadap mencit putih jantan dengan metode bersihan karbon. Dosis ekstrak etanol kulit buah nanas yang paling baik untuk efek imunomodulator adalah dosis $250 \mathrm{mg} / \mathrm{kgBB}$.

\section{UCAPAN TERIMA KASIH}

Almamater STIFI Bhakti Pertiwi Palembang.

\section{PUSTAKA}

1. Cahyono, B. 2012. Budidaya Nenas Secara Komersial. Jakarta: Pustaka Mina.

2. Chao, S., Schreuder, M., Young, G., Nakaoka, K., Moyes, L., dan Oberg, C. 2004. Pre-Clinical study: Antioxidant levels and immunomodulatory effect of wolfberry juice and other mixtures in mice. The journal of the american nutraceutical association, 7 (1), 32-38.

3. Departemen farmakologi dan terapeutik FKUI. 2012. Farmakologi dan Terapi. Jakarta: Badan Penerbit FKUI.

4. Emmanuel, E.U., Onagbonfeoana, E.S., Adanma, O.C., Precious, O.C., Faith, A., dan Ndukaku, O.Y. 2016. In Vivo and in vitro antioxidant and hypolipidemic activity of methanol extract of pineapple peels in wistar rats. International Journal of Biosciences, 8(6), 64-72.

5. Francis, G., Zohar, K., Harinder, P.S.M., dan Klaus, B. 2002. The biological action of saponins in animals sistems. British Journal of Nutrition, 88, 587-605.

6. Hatam, S.F., Suryanto, E., dan Abidjulu, J. 2013. Aktivitas antioksidan dari ekstrak kulit nanas (Ananas comosus (L.) merr). Jurnal Ilmiah Farmasi, 2(01), 8-11.

7. Imron, R., Supriatiningsih, dan Firdaus, S. 2016. Biologi Dasar Manusia. Jakarta: CV. Trans Info Media.

8. Kafeel, H., Sheikh, D., Naqvi, S.B.S., dan Ishaq, H. 2016. Antidepressant activity on methanolic extract of Ananas comosus linn peel (meacp) by using forced swim and tail suspension apparatus in mice. Sciences International (Lahore), 28(3), 2525-2531.

9. Kalaiselv, M., Gomathi, D., Ragavendran, P., Bhuvaneshwari, V., Amsaveni, R., Devaki, K., dan Uma, C. 2015. Modulatory effect of Ananus comosus (L.) peel on dmba induced mammary cancer in rat model. International Journal of Biosciences and Nanosciences, 2(12), 230-240.

10. Kumaunang, M., dan Kamu, V. 2011. Aktivitas enzim bromelain dari ekstrak kulit nenas (Ananas comosus). Jurnal Ilmiah Sains, 11(2), 199-201.

11. Manaroinsong, A., Abidjulu, J., dan Siagian, K. V. 2015. Uji daya hambat ekstrak kulit nanas (Ananas comosus L.) terhadap bakteri staphylococcus aureus secara in vitro. Jurnal IImiah Farmasi - UNSRAT, 4(4), 27-33. 
12. Marjoni, R. 2016. Dasar-Dasar Fitokimia. Jakarta timur: CV. Trans Info Media.

13. Nassar, m., Zerizer, S., Karbouche, Z., Kabouche, A., dan Bechkri, S. 2015. Antioxidant and the immunomodulatory activities exhibited by three plants from lamiaceae family. International Journal of Pharmacy and Pharmaceutical Sciences, 7(9), 331-334.

14. Nugroho, Y.A. 2012. Efek pemberian kombinasi buah sirih (Piper betle L) fruit, daun minaya (Plectranthus scutellarioides (L.) R. BR.) leaf, madu dan kuning telur terhadap peningkatan aktivitas dan kapasitas fagositosis sel makrofag. Media Litbang Kesehatan, 22(1), 1-5.

15. Praveena, J., dan Estherlydia, D. 2014. Comparative study of phytochemical screening and antioxodant capacities of vinegar made from peel and fruit of pineapple (Ananas comosus L.). International Journal of Pharma and Biosciences, 5(4), 394 - 403.
16. Ramadhiani, A. R. 2015. Pengaruh ekstrak etanol kulit buah nanas (Ananas comosus (L.) Merr.) terhadap glukosa darah dan kadar superoksida dismutase (SOD) pada mencit hiperglikemia secara in vivo. (Skripsi). Medan: Universitas Sumatera Utara.

17. Shah, A.S., Wakade, A.S., dan Juvekar, A.R. 2008. Immunomodulatory activity of methanolic extract of Murraya koenigii (L.) spreng leaves. Indian Journal of Experimental Biology, 46, 505-509.

18. Tizard, I.R. 2000. Immunology: An Introduction (Edisi VI). New York: Saunders College Publishing.

19. Tjay, T.H. dan Rahardja, K. 2007. Obat-obat penting: khasiat, penggunaan dan efek-efek sampingnya (Edisi VI). Jakarta: PT Elex Media Komputindo. 